\title{
A retrospective study to assess and correlate maternal periodontal status with term of pregnancy and weight of newborn
}

\author{
Mayuri N. Jain ${ }^{1}$, Girish Suragimath ${ }^{1 *}$, Siddhartha A. Varma ${ }^{1}$, \\ Sameer Anil Zope ${ }^{1}$, Ashwini S. R. ${ }^{2}$
}

${ }^{1}$ Department of Periodontology, ${ }^{2}$ Department of Oral Medicine and Radiology, Krishna Institute of Medical Sciences, School of Dental Sciences, Karad, Maharashtra, India

Received: 07 August 2017

Accepted: 04 September 2017

*Correspondence:

Dr. Girish Suragimath,

E-mail: drgirishsuragimath@gmail.com

Copyright: (c) the author(s), publisher and licensee Medip Academy. This is an open-access article distributed under the terms of the Creative Commons Attribution Non-Commercial License, which permits unrestricted non-commercial use, distribution, and reproduction in any medium, provided the original work is properly cited.

\begin{abstract}
Background: Periodontitis is an inflammatory disease affecting the tooth supporting structures; studies have shown that it also affects the systemic health and conditions like pregnancy. With this background the present retrospective study was conducted to assess and correlate periodontal status of pregnant women with their pregnancy outcome.

Methods: A total of 150 pregnant women two days postpartum were examined for periodontal status using following parameters: Oral hygiene index- simplified (OHI-S), modified gingival index (MGI), probing pocket depth (PPD) and clinical attachment loss (CAL). The level of education, body mass index (BMI), gestational age and weight of the baby were recorded and correlated with the periodontal status.

Results: Out of 150 women, $83(55.3 \%)$ women suffered from gingivitis and 67 (44.7\%) had periodontitis. The incidence of preterm low birth weight babies was seen in 65 (43.33\%) women. Body mass index, education level and periodontal disease were significantly associated with preterm low birth weight infants.

Conclusions: A significant association was found between periodontitis and preterm low birth infants. The promotion of early detection and treatment of periodontal diseases in women before and during pregnancy will be beneficial. This will minimize the cost of post natal care and morbidity in the new born.
\end{abstract}

Keywords: Low birth weight, Periodontal disease, Pregnancy, Preterm

\section{INTRODUCTION}

Preterm birth is defined by WHO as all the births complet ed before 37 weeks of gestation or fewer than 259 days, since the first day of last menstrual cycle. Low birth weight infants are those that weigh less than $2500 \mathrm{gm}$ at the time of birth. ${ }^{1}$ This is of special interest for public health because these are major causes of neonatal mortality and ample long term morbidity such as intellectual, learning and visual disability. Maternal factors such as age, tobacco use, poor oral health, education level, socioeconomic status and BMI play an important role in preterm low birth weight babies. ${ }^{2}$
Periodontal disease is a complex infectious disease caused by multiple micro-organisms like anaerobic, gram- negative and microaerophilic bacteria colonizing at sub gingival area. ${ }^{3}$ This results because of plaque deposition on the tooth and root surfaces. Dental plaque is nothing but the biofilm made up of periodontopathic microorganisms. These organisms trigger inflammatory mediators such as interlukin-1 $\beta$, interlukin-6, prostaglandin $E_{2}$, TNF- $\alpha{ }^{4}$ These inflammatory mediators act on hard and soft tissues and destroy the periodontal structures which support the tooth.

Periodontitis activates inflammatory mediators which destroy the tooth supporting structures and releases 
prostanoids and proteases which results either into uterine muscle contraction: premature labor or premature rupture of membrane. ${ }^{5}$ As there is high prevalence of preterm low birth weight deliveries in south Asian countries including India, the present study was aimed at elucidating the factors responsible for preterm low birth weight babies (PTLBW). Hence, this retrospective study was conducted to assess the relationship between preterm low weight newborns and maternal periodontal status, so as to provide basis for recommending oral health care in pregnant women.

\section{METHODS}

A total of 150 pregnant women within two days (48 hours) postpartum were randomly selected for the study and examined. Patients were educated about the objectives of the study and an informed consent was obtained before enrolling them in the study. The study was conducted in primary health care centers, Karad after due approval of ethical committee from Krishna institute of medical sciences deemed university, Karad [Ref. No. KIMSDU/IEC/03/2015] the study was conducted during the period of December 2015 to June 2016.

Pregnant women aged 18-37 years were included in the study. Women who had positive history of HIV, AIDS, and any systemic disorders affecting pregnancy outcome, bacterial vaginosis, alcohol and drug abuse were excluded from the study. A single calibrated examiner recorded all the periodontal parameters under supervision of a senior periodontist. The periodontal examination was carried out bed side of patient with help of a torch light for illumination with sterile instruments, as postpartum women were unable to visit dental clinic.

The periodontal status was recorded using following parameters, oral hygiene index- simplified (OHI-S), modified gingival index (MGI), probing pocket depth (PPD), clinical attachment level (CAL). The oral hygiene index-simplified given by John C Green in 1964 was used to assess oral hygiene status. The oral hygiene status of entire mouth was graded according to OHI-S score. The grading were as follows: good: 0.1-1.2, fair: 1.3-3.0, poor: $3.1-6 .^{6}$

Modified gingival index (MGI) was measured using R.R. Lobene, T. Weather-ford, N.M. Ross, R.A. Lamm and L. Menaker modified gingival index, 1986. Modified gingival index for entire mouth was determined by dividing the total score by number of surfaces examined; score 0.1-1 was considered as mild gingivitis, score 1.1-2 was considered as moderate gingivitis and score 2.1-3 was considered as severe gingivitis. ${ }^{6}$

The level of PPD and CAL were determined by using University of North Carolina -15 (UNC NC, Hu-Friedy, Roterandum, Netherland) probe. The probe was inserted along the vertical axis and walked around the tooth by using a standardized pressure on each tooth. Measurements were recorded from all four surfaces of tooth. The probing pocket depth was measured from free gingival margin to base of gingival sulcus, while clinical attachment loss was recorded from cementoenamel junction (CEJ) to base of gingival sulcus.

Apart from periodontal parameters, the general parameters such as, economical status and body mass index (BMI) were recorded. ${ }^{7}$ The BMI was calculated based on formula: body weight in kilograms divided by height in meters squared.

The study participants were divided into two groups as gingivitis group and periodontitis group. Delivery data was obtained from their gynecological record which included, weight of newborn baby, gestational age (term of pregnancy), and type of delivery.

\section{Statistical analysis}

All the data collected was statistically analyzed using Statistical Package for Social Sciences (SPSS) software (version 19, IBM Corporation, Armonk, New York, USA). The results were expressed in means and percentage, $\mathrm{p} \leq 0.05$ was considered significant. The significance of difference in means was tested by ANOVA test. Turkey's test was used to explore the association between explanatory variables.

\section{RESULTS}

Out of 150 women, $17(11.33 \%)$ women were less than 20 years. Only $3(2 \%)$ women were more than 35 years old. Maximum number of women i.e. 71 (47.33\%) were in age group of 21-25years (Table 1).

Table 1: Demographic table showing age group.

\begin{tabular}{|lll|}
\hline Age group & No. of patients & Percentage (\%) \\
\hline$<20$ & 17 & 11.33 \\
\hline $21-25$ & 71 & 47.33 \\
\hline $26-30$ & 48 & 31.33 \\
\hline $31-35$ & 11 & 8 \\
\hline$>35$ & 3 & 2 \\
\hline Total & 150 & 100 \\
\hline
\end{tabular}

The economic status of women showed that the $90(60 \%)$ of the participants were in low income group (Table 2).

Table 2: Demographic table showing economic status.

\begin{tabular}{|lll|}
\hline Economic status & No. of patients & $\%$ \\
\hline$\geq 36,997$ & 19 & 12.67 \\
\hline $18,498-36,996$ & 28 & 18.67 \\
\hline $13,874-18,497$ & 13 & 8.67 \\
\hline $9,249-13,873$ & 45 & 30 \\
\hline $5547-9248$ & 27 & 18 \\
\hline $1866-5546$ & 18 & 12 \\
\hline$\leq 1865$ & 0 & 0 \\
\hline Total & 150 & 100 \\
\hline
\end{tabular}


The education level of the women showed that most of them were not well educated and maximum of them had middle school certificate $62(41.33 \%)$ and three $(2 \%)$ women were illiterate (Table 3 ).

Table 3: Demographic table showing education level.

\begin{tabular}{|lll|}
\hline Education level & No. of patients & $\%$ \\
\hline Profession or honor's & 2 & 1.33 \\
\hline Graduate or postgraduate & 28 & 18.67 \\
\hline Post high school diploma & 29 & 19.33 \\
\hline High school certificate & 18 & 12 \\
\hline Middle school certificate & 62 & 41.33 \\
\hline Primary school certificate & 8 & 5.33 \\
\hline Illiterate & 3 & 2 \\
\hline Total & 150 & 100 \\
\hline
\end{tabular}

The periodontal status showed that out of 150 women, 83 $(55.3 \%)$ suffered from gingivitis and 67 (44.7\%) suffered from periodontitis (Table 4).
Table 4: Periodontal status of pregnant women.

\begin{tabular}{|lll|}
\hline $\begin{array}{l}\text { Periodontal } \\
\text { disease severity }\end{array}$ & No. of patients & Percentage $(\%)$ \\
\hline Gingivitis & 83 & 55.3 \\
\hline Periodontitis & 67 & 44.7 \\
\hline
\end{tabular}

The current table depicts a significant association between birth weight and term of pregnancy. The 98 women $(65 \%)$ gave birth to low birth weight babies. Out of these 98 women, 65 were preterm and 33 were full term. In our study, 110 women $(73.33 \%)$ gave birth to preterm babies out of which 65 were low birth and 45 were normal weight babies $(\mathrm{p}<0.05)$ (Table 5). Among women with middle school certificate $24(16 \%)$ women delivered low birth weight babies while 43 (28.66\%) women gave preterm birth.

Education level and pregnancy outcome did not show any significant association (Table 6).

Table 5: Association between birth weight and term of pregnancy.

\begin{tabular}{|lllll|} 
Birth weight & Low birth weight $(\%)$ & Normal birth weight $(\%)$ & Total (\%) & P value \\
\hline Preterm & $65(43.33)$ & $45(30)$ & $110(73.33)$ & $0.011^{*}$ \\
\hline Fullterm & $33(22)$ & $7(4.66)$ & $40(28.66)$ & $150(100)$ \\
\hline Total & $98(65.33)$ & $52(34.66)$ &
\end{tabular}

*P-value $<0.05$ was considered statistically significant.

Table 6: Association of education level with birth weight and gestational age.

\begin{tabular}{|c|c|c|c|c|c|c|c|c|}
\hline Education & Illiterate & Primary & $\begin{array}{l}\text { Middle } \\
\text { school }\end{array}$ & $\begin{array}{l}\text { High } \\
\text { school }\end{array}$ & $\begin{array}{l}\text { Post-high } \\
\text { school }\end{array}$ & $\begin{array}{l}\text { UG or } \\
\text { PG }\end{array}$ & Profession & P value \\
\hline Birth weight & & & & & & & & \multirow{3}{*}{$\begin{array}{l}\chi 2=8.53, \\
p=0.20\end{array}$} \\
\hline Normal birth weight & - & 5 & 38 & 12 & 20 & 21 & 2 & \\
\hline Low birth weight & 3 & 3 & 24 & 6 & 9 & 7 & - & \\
\hline Gestational age & & & & & & & & \multirow{3}{*}{$\begin{array}{l}\chi^{2}=3.31 \\
p=0.77\end{array}$} \\
\hline Preterm & 3 & 6 & 43 & 12 & 23 & 21 & 2 & \\
\hline Fullterm & - & 2 & 19 & 6 & 6 & 7 & - & \\
\hline
\end{tabular}

*P-value $\leq 0.05$ was considered statistically significant.

Out of 150 women, 27 (18\%) of them were found to be underweight out of which $16(10.66 \%)$ women delivered low birth weight babies and 11 delivered normal weight babies. Out of these 27 underweight women, 25 (16.66\%) delivered preterm baby and 2 delivered full term babies. BMI was found to be in significant association $(p=0.01)$ with birth weight while gestational age did not show significant association (Table 7).

A significant association was found between birth weight and economic status while no significant association is found between gestational age and economic status (Table 8).

Periodontitis was observed in 67 (44.66\%) women out of which, $30(44.77 \%)$ delivered low birth weight babies and $37(55.22 \%)$ delivered normal weight babies.

Out of 67 women who suffered from periodontitis, 56 $(83.58 \%)$ delivered preterm babies while 11 (16.41\%) delivered full term babies. A significant association was found between periodontal disease severity, birth weight and gestational age (Table 9). 
Table 7: Association of BMI with birth weight and gestational age.

\begin{tabular}{|c|c|c|c|c|c|c|}
\hline BMI & Underweight & Normal & Overweight & Obese & Morbidly obese & $P$ value \\
\hline \multicolumn{6}{|l|}{ Birth weight } & \multirow{3}{*}{$\chi 2=14.57, p=0.01 *$} \\
\hline Normal birth weight & 11 & 57 & 24 & 6 & - & \\
\hline Low birth weight & 16 & 26 & 6 & 3 & 1 & \\
\hline \multicolumn{6}{|l|}{ Gestational age } & \multirow{3}{*}{$\chi^{2}=7.98, p=0.16$} \\
\hline Preterm & 25 & 55 & 22 & 7 & 1 & \\
\hline Fullterm & 2 & 28 & 8 & 2 & - & \\
\hline
\end{tabular}

*P-value $\leq 0.05$ was considered statistically significant.

Table 8: Association of economic status with birth weight and gestational age.

\begin{tabular}{|c|c|c|c|c|c|c|c|c|}
\hline Economic status & $\leq 1865$ & $\begin{array}{l}1866- \\
5546\end{array}$ & $\begin{array}{l}5547- \\
9248\end{array}$ & $\begin{array}{l}9,249- \\
13,873\end{array}$ & $\begin{array}{l}13,874- \\
18,497\end{array}$ & $\begin{array}{l}18,498- \\
36,996\end{array}$ & $\geq 36,997$ & P value \\
\hline \multicolumn{8}{|l|}{ Birth weight } & \multirow{3}{*}{$\mathrm{p}=0.014^{*}$} \\
\hline Normal birth weight & 0 & 7 & 14 & 33 & 8 & 24 & 12 & \\
\hline Low birth weight & 0 & 11 & 13 & 12 & 5 & 4 & 7 & \\
\hline \multicolumn{8}{|l|}{ Gestational age } & \multirow{3}{*}{$\mathrm{p}=0.098$} \\
\hline Preterm & 0 & 13 & 24 & 30 & 9 & 17 & 17 & \\
\hline Fullterm & 0 & 5 & 3 & 15 & 4 & 11 & 2 & \\
\hline
\end{tabular}

*P-value $\leq 0.05$ was considered statistically significant.

Table 9: Association of periodontal disease severity with birth weight and gestational age.

\begin{tabular}{|c|c|c|c|}
\hline Periodontal disease severity & Gingivitis & Periodontitis & P-value \\
\hline \multicolumn{3}{|l|}{ Birth weight } & \multirow{3}{*}{$\chi 2=5.46, p=0.02 *$} \\
\hline Normal birth weight & 61 & 37 & \\
\hline Low birth weight & 22 & 30 & \\
\hline \multicolumn{3}{|l|}{ Gestational age } & \multirow{3}{*}{$\chi 2=6.5, p=0.01 *$} \\
\hline Preterm & 54 & 56 & \\
\hline Fullterm & 29 & 11 & \\
\hline
\end{tabular}

*P-value $<0.05$ was considered statistically significant.

\section{DISCUSSION}

One of the important health problems worldwide today is preterm and low birth weight babies, as these factors are common causes of neonatal morbidity and mortality. Numerous factors have been associated with PTLBW babies. Age, tobacco chewing, education level, economic status, poor oral health and nutritional status are leading factors to be considered. ${ }^{2}$ Despite the efforts taken by WHO and UNICEF the rate of PTLBW has not reduced. Thus, some more factors can be related to PTLBW which are yet to be explored.

The incidence of PTLBW babies in current study was found to be $43.33 \%$.The results shows higher rate than those published by UNICEF, who mentioned that prevalence of low birth weight babies is $30 \%$ in south Asian countries. ${ }^{8}$ Use of smokeless tobacco in the form of mishri is higher in this region which could have led to deficit birth weight and gestational age. ${ }^{9}$ Women with low BMI, lack of antenatal visits and poor nutritional determinants can also lead to PTLBW babies. ${ }^{10}$
Noack et al reported that, as the age of pregnant women increased the risk of PTLBW increased (mean 27.8 \pm 5.3 years). ${ }^{11}$ This is found to be contrary to our results, where majority $(47.33 \%)$ of women were middle aged women (21-25 years). This may be because of tendency of Indian society to marry girls at younger age.

The educational status recorded in our study revealed that majority of women had middle school certificate $(41.33 \%)$. In our study, no significant association was found between level of education, preterm and low birth weight babies. These results are similar to Lohana et al and Lopez et al who stated that there is no significant relation between education level and PTLBW babies. ${ }^{3,12}$ The results are contradictory to those stated by Radnai et al and Davenport et al who reported that both maternal and paternal education influence, the birth weight of babies. $^{13,14}$

The current study demonstrates that with decrease in BMI, there was an increase in prevalence of PTLBW babies, this was due to babies nutritional status was hampered due to mother's inadequate nutritional 
determinants and lack of antenatal care. In current study, the relationship of BMI to PTLBW babies was statistically significant. The results are similar to the findings reported by Buduneli et al and Lohana et al who reported that mothers who delivered PTLBW babies gained significantly less weight during the pregnancy. ${ }^{12,15}$ The above results are contradictory to those reported by Romero et al who stated that BMI does not have significant relation to PTLBW. ${ }^{16}$ The contradictory results of present study to Romero et al may be due to the difference in the population of study subjects.

Current results show a significant association between economical status and birth weight. The results are in accordance to study conducted by Kramer and Kaunas who found that poor economic conditions lead to low birth weight babies. ${ }^{17,18}$ Contrary to Secher et al in Malaysian case- control population who reported that lower economical income is not a risk factor for low birth weight babies. ${ }^{19}$

The study by Offenbacher et al and Hunter et al colleagues suggested that maternal periodontal disease could lead to a seven fold increased risk of delivery of a PTLBW babies. ${ }^{20,21}$ Women who have low birth weight babies as a consequence of either premature rupture of membrane or preterm labour tend to have increased severity of periodontal disease than mothers with normal birth weight infants. ${ }^{21}$ According to present study, periodontal disease was found to be significantly associated with PTLBW.

Among women in periodontitis group, $44.77 \%$ delivered low birth weight babies and $55.22 \%$ delivered preterm. These results are in accordance with study conducted by Mokeem, Siqueira et al, Rajapakse, Toygar et al, Agueda et al who concluded that periodontal disease was rife in mother's who delivered PTLBW babies than in mothers who delivered full term normal weight infants. ${ }^{22-26}$ Direct or indirect effect of inflammatory mediators of periodontal disease on the developing foetus could manipulate pregnancy outcome.

The results were contradictory to Noack et al, Moore et al, Nabet et al, Vettore et al, Bassaniet al who stated that periodontitis was not a detectable risk factor for PTLBW babies. ${ }^{11,27-30}$ The difference in the results could be because of difference in characteristics and race of the study population.

In the current study, prevalence of PTLBW was $43.33 \%$, which is higher than national average of Indian population $(23 \%){ }^{31}$ This high prevalence of PTLBW in this study area could be reflection of poor maternal health conditions, age, tobacco chewing, education level, economic status, poor oral health, nutritional status and inadequate health care services in rural areas. Our findings collectively suggest that, periodontitis is an independent risk factor for PTLBW.

\section{ACKNOWLEDGMENTS}

The current study states that periodontitis is a possible risk factor for PTLBW babies. Within the limitations of the study, it can be concluded that periodontitis, BMI and economical status could be a significant risk factor for PTLBW babies. Hence, cooperation between gynecologists and dentists should be developed. The dentist must have an important role in encouraging pregnant women for maintaining desirable oral health hygiene and educating them about adverse pregnancy outcomes due to poor periodontal status, which will reduce the incidence of PTLBW babies.

\section{Funding: No funding sources \\ Conflict of interest: None declared}

Ethical approval: The study was approved by the Institutional Ethics Committee from Krishna institute of medical sciences deemed university, Karad [Ref. No. KIMSDU/IEC/03/2015]

\section{REFERENCES}

1. World Health Organization. International classification of diseases and related health problems. Tenth revision. Geneva, WHO, 1993.

2. Shanthi V, Vanka A. Bhambal A, Saxena V, Saxena S, Kumar SS. Association of pregnant women periodontal status to preterm and low-birth weight babies: A systematic and evidence-based review. Dent Res J. 2012;9(4):368-80.

3. Lopez N.J, Smith PC, Guiterrez J. Higher risk of preterm birth and low birth weight in women with periodontal disease. J Dent Res. 2002;81:58-63.

4. McGaw T. Periodontal disease and preterm delivery of low-birth-weight infants. J Can Dent Assoc. 2002;68(3):165-9.

5. Bey A, Gupta ND, Khan S, Ashfaq N, Hadi SA. Periodontitis: a significant risk factor for preterm low birth weight (PTLBW) babies. Biol Med. 2011;3:158-63.

6. Peter S. Essentials of Public health dentistry.5th edition. New Delhi: Aryamedi publishing house; 2013.

7. Sharma R, Saini NK. A Critical Appraisal of Kuppuswamy's Socioeconomic Status Scale in the Present Scenario. J Family Med Prim Care. 2014;3:3-4.

8. UNICEF: Low birth weight: Country, regional and global estimates. 2004, United Nations Children's Fund.

9. Krishna K. Tobacco chewing in pregnancy. Br $\mathrm{J}$ Obstet Gynecol. 1978;85:726-8.

10. Ohlsson A, Shah P. Determinants and prevention of low birth weight: A synopsis of the evidence. Edmonton: Institute of Health Economics (IHE); 2008: 2-284.

11. Noack B, Klingenberg J, Weigelt J, Hoffmann T. Periodontal status and preterm low Birth weight: A 
case control study. J Periodontal Res. 2005;40:33945 .

12. Lohana MH, Suragimath G, Patange RP, Varma S, Zope SA. A Prospective Cohort Study to Assess and Correlate the Maternal Periodontal Status with Their Pregnancy Outcome. J Obstet Gynecol India. 2017;67(1):27-32.

13. Radnai M, Gorzo I, Nagy E, Urban E, Novak T, Pal A. A possible association between preterm birth and early periodontitis.A pilot study. J Clin Periodontol. 2004;31:736-41.

14. Davenport ES, Williams CE, Sterne JA, Sivapathasundram V, Fearna JM, Curtis MA. The east London study of maternal chronic periodontal disease and preterm low birth weight infants: study design and prevalence data. Ann Periodontol. 1998;3(1):213-21

15. Buduneli N, Baylas H, Buduneli E, Turkoglu O. Dahlen G. Evaluation of the relationship between smoking during pregnancy and subgingival microbiota. J Clin Periodontol. 2005;32:68-74.

16. Romero BC, Chiquito CS, Elejalde LE, Bernardoni CB. Relationship between periodntal disease in pregnant women and the nutritional condition of their newborns. J Periodontol. 2002;73:1177-83.

17. Kramer MS. Determinants of low birth weight: methodological assessment and Meta-analysis. Bull World Health Organ. 1987;65:663-737.

18. Dickute J, Padaiga Z, Grabauskas V, Nadišauskienè RJ, Basys V, Gaižaukienè A. Maternal socio-economic factors and the risk of low birth weight in Lithuania. Medicina (Kaunas). 2004;40:475-82.

19. Secher NJ, Kern Hansen P, Thomsen BL, Keiding N. Growth retardation in preterm infants. $\mathrm{Br} \mathrm{J}$ Obstet Gynaecol. 1987;94(2):115-20.

20. Schneider HG, Göbbels E, Apel EM. Simplification of plaque index method of Quigley and Hein. Stomatol DDR. 1989;39(2):91-4.

21. Hunter W. Oral sepsis as a cause of disease. Br Med J. 1900;2(2065):215-6.

22. Lohsoonthorn V, Kungsadalpipob K, Chanchareonsook P, Limpongsanurak S, Vanichjakvong O, Sutdhibhisal S, et al. Is maternal periodontal disease a risk factor for preterm delivery. Am J Epidemol. 2009;169:731-9.
23. Siqueira FM, Cota LO, Costa JE, Haddad JP, Lana AM, Costa FO. Intrauterine growth restriction, low birth weight, and preterm birth: Adverse pregnancy outcomes and their association with maternal periodontitis. J Periodontol. 2007;78:2266-76.

24. Rajapakse PS, Nagarathne M, Chandrasekra KB, Dasanayake AP. Periodontal disease and prematurity among non-smoking Sri Lankan women. J Dent Res. 2005;84:274-7.

25. Toygar HU, Seydaoglu G, Kurklu S, Guzeldemir E, Arpak N. Periodontal health and adverse pregnancy outcome in 3,576 Turkish women. J Periodontol. 2007;78:2081-94.

26. Agueda A, Ramón JM, Manau C, Guerrero A, Echeverría JJ. Periodontal disease as a risk factor for adverse pregnancy outcomes: A prospective cohort study. J Clin Periodontol. 2008;35:16-22.

27. Moore S, Ide M, Coward PY, Randhawa M, Borkowska E, Baylis R, et al. A prospective study to investigate the relationship between periodontal disease and adverse pregnancy outcome. Br Dent J. 2004;197:251-8.

28. Nabet C, Lelong N, Colombier ML, Sixou M, Musset AM, Goffinet F, et al. Maternal periodontitis and the causes of preterm birth: The case-control Epipap study. J Clin Periodontol. 2010;37:37-45.

29. Vettore MV, Leal MD, Leão AT, Da Silva AM, Lamarca GA, Sheiham A. The relationship between periodontitis and preterm low birth weight. J Dent Res. 2008;87:73-8.

30. Bassani DG, Olinto MT, Kreiger N. Periodontal disease and perinatal outcomes: A case-control study. J Clin Periodontol. 2007;34:31-9.

31. Boarh M, Agarwalla R. Maternal and sociodemographic determinants of low birth weight (LBW): A community-based study in a rural block of Assam. P Postgard Med 2016;62:178-81.

Cite this article as: Jain MN, Suragimath G, Varma SA, Zope SA, Ashwini SR. A retrospective study to assess and correlate maternal periodontal status with term of pregnancy and weight of newborn. Int J Reprod Contracept Obstet Gynecol 2017;6:4589-94. 